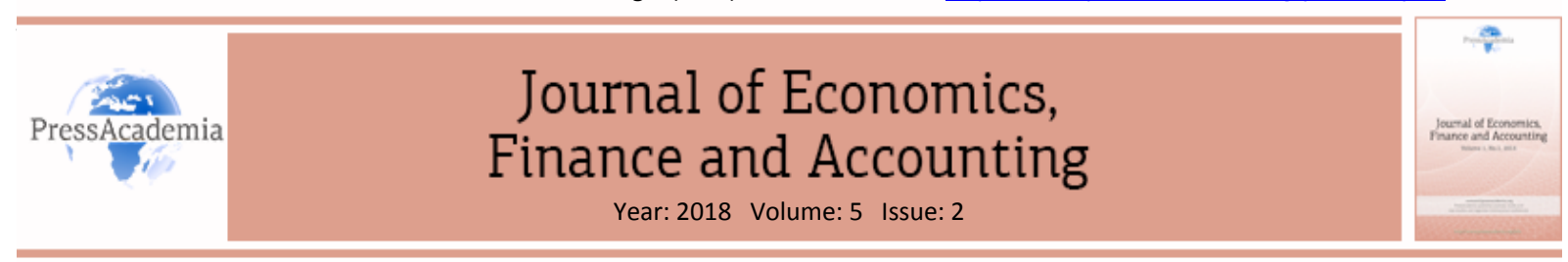

\title{
OWNERSHIP STRUCTURES AND CHARACTERISTICS INFLUENCE ON AUDIT FEE
}

\author{
DOI: $10.17261 /$ Pressacademia.2018.822 \\ JEFA- V.5-ISS.2-2018(2)-p.160-167
}

\author{
Juan Octavianus Harahap ${ }^{1}$, Andrian Budi Prasetyo ${ }^{2}$ \\ ${ }^{1}$ Diponegoro University, Accounting Department, Faculty of Economics and Business, Tembalang, Semarang City, Central Java, Indonesia. \\ harahapjuan.jh@gmail.com, ORCID: 0000-0002-5144-8361 \\ 2 Diponegoro University, Accounting Department, Faculty of Economics and Business, Tembalang, Semarang City, Central Java, Indonesia. \\ andrianbp1589@gmail.com, ORCID: 0000-0002-4332-6241
}

\section{To cite this document}

Harahap, J.O., Prasetyo, A.B. (2018). Ownership structures and characteristics influence on audit fee. Journal of Economics, Finance and Accounting (JEFA), V.5(2), p.160-167.

Permemant link to this document: http://doi.org/10.17261/Pressacademia.2018.822

Copyright: Published by PressAcademia and limited licenced re-use rights only.

\begin{abstract}
Purpose - The purpose of this paper was to investigate the influence of the structures and characteristics of corporate ownership on audit fees paid to external auditors by Indonesian companies listed on Indonesian Stock Exchange (ISE).

Methodology - The population of this research was non-financial companies listed in Indonesia Stock Exchange during the period of 20142016 that were sampled using purposive sampling method resulted in 150 companies met the criteria. Data collected were then analyzed using multiple linear regression analysis. The dependent variable was the level of audit fees charged to the client by an external audit represented as AFEE, measured in the Indonesia rupiah. Meanwhile, the independent variables were ownership structure of the company consisted of: (1) managerial ownership, (2) foreign ownership, (3) government ownership; and characteristics structure, which is divided into: (4) complexity, (5) current ratio, (6) leverage, (7) profitability.

Findings- The results showed that firms with larger foreign ownership, on government ownership, and on profitability significantly and positively affected audit fees, but higher managerial ownership significantly and negatively affected firms with audit fees. The results also showed the insignificant relationship between complexity, current ratio and leverage and audit fees.

Conclusion- Managerial Ownership, Foreign ownership, government ownership, and profitability influence on audit fee for external auditor.
\end{abstract}

Keywords: Ownership structure, audit fees, firm characteristics, agency theory, Indonesia.

JEL Codes: M40, M41, M42

\section{INTRODUCTION}

The cases of Enron and Arthur Anderson (Griffin, Lont, \& Sun, 2009) as well as PT. Kereta Api Indonesia have greatly affected the reputation of the accounting profession and financial reporting companies. These accounting cases illustrates the importance of having strong corporate governance to improve the reporting of financial statements and the quality of the audit. In this regard, internal and external oversight mechanisms have been suggested to solve or at least reduce the possible fraud to happen. As a result, auditor's work is receiving attention from the users of the financial statements, especially shareholders, to ensure the reliability and the credibility of the company's financial statements. This obligation becomes more complex as the structure and the characteristic of the corporate ownership are specific.

Differences of companies' ownership structure causes differences in the mechanisms of controlling conducted by shareholders in overseeing the company's business activities, including financial statement reporting process. Inefficiency and malfunctioning of the corporate governance mechanisms is the major factor of cases (Mazlina Mustapha \& Ayoib Che Ahmad, 2011) which might cause by difference monitoring mechanism as well as financial statement reporting process (Yatim, Kent, \& Clarkson,2006). Previous studies have shown that the audit fees paid to the external auditors varies depending on the structure of corporate ownership (Mitra, Hossain, \& Deis, 2007; Adelopo, Jallow, \& Scott, 2012). However, few research discussing the ownership structure of the company as one of the corporate governance in audit costs available. Most studies examined the cases in the developed countries such as Finland (Niemi, 2005), America (Mitra et al., 2007) and England (Adelopo et al., 2012). 
Given this situation, the purpose of this paper was to investigate the influence of the structures and characteristics of corporate ownership on audit fees paid to external auditors by Indonesian companies listed on Indonesian Stock Exchange (ISE). In this study, the corporate ownership structure was divided into ownership manager, foreign ownership, and the ownership of the government associated with audit fee. The corporate characteristics, which was divided into complexity, profitability, and company risk also related to audit fee.

This paper is organized in the following part. Section 2 reviews agency theory underlying the background of the hypotheses and elaborate the relationship between audit fee and management ownership, foreign ownership, government ownership, complexity, current ration, leverage, and profitability. Section 3 describes the methodology developed in this study covering variables, sample selection, and method of analysis. Section 4 elaborates steps of conducting data analysis and explains the empirical results, and finally, section 5 , concludes the paper.

\section{LITERATURE REVIEW}

\subsection{Hypotheses Development}

In this research, agency theory was applied to predict companies with dispersed ownership or separately as government and foreign ownership. Agency theory is a contractual relationship that occurs between the principal who uses the agent to carry out the services in accordance with the interests of the principal in the event of separation of ownership and control of companies (Jensen \& Meckling, 1976). This causes the internal control auditor dubious clients and improve substantive tests to the extent that is necessary (Chan, Ezzamel, \& Gwilliam, 1993). As a result, auditor requires more time and labor costs in providing audit services.

Researches focusing on the effect of the ownership on the audit cost have also been conducted in Indonesia. Oktorina and Wedari (2015) concluded that managerial ownership, audit committee activity, firm size, liquidity ratios, profitability ratios affect audit fees. Next, Baldacchino, et al. (2014) identified that Client size, complexity, risk, ownership control, and corporate status affect the amount of audit fee. Meanwhile, research upon factors influencing audit fee conducted by Gammal (2012) showed that the size of KAP is the most important factor affecting audit fee.

Agency theory is a relevant theory to explain the mechanism of how the company's ownership structure can affect the cost of agency that relates to significant positive internal controls. In this sense, the presence of corporate governance mechanisms would improve supervision of the management of the company in order to reduce error reporting process of the financial statements (Hogan \& Wilkins, 2008). The cost of agency referred to in this research was the cost of the audit.

On the other side, the corporate ownership structure is as concentrated as managerial ownership is expected to have a strong risk control mechanism. This makes the auditor to exert less effort and time to perform audit services to the company resulting in a decrease in audit fees charged to the client-party auditor

\subsection{Management Ownership on Audit Fees}

Jensen \& Meckling (1976) stated that according to agency theory, the separation between manager and owner of a company reduces agency costs taken by managers. Therefore, previous studies suggested manager to own company's shares as a supporting oversight manager to enhance internal control and reduce audit costs. The greater the proportion of their holdings, the more responsible the managers to increase the value of a company will be.

Meanwhile, Mustapha and Che Ahmad (2011) proved that managerial ownership has inversed relationship with monitoring costs. This is consistent with agency theory that the amount of monitoring costs will be lower if the proportion of the ownership structure mostly owned by director or management that obliged management to access more information and manage the resources of the company adequately. This supported the previous studies conducted by Nelson \& Rusdi (2015). Therefore, it is hypothesized that

H1: firms with large managerial ownership are likely to have lower audit fees

\subsection{Foreign Ownership on Audit Fees}

Jensen \& Meckling (1976) stated that according to agency theory there is a difference interest between the principal or the owner of the company and the agent or manager. In fact, managers do not always run the company according to the goals of the owner instead using the authority to fulfill his/her personal interests. The problem will be more complex when it takes place in foreign companies, as audit fee to be paid for the external auditor is the major concern.

In the foreign company, audit fees will increase susbstantially due to the complexity of the financial statement because of geographic separation and different accounting standard between parents and its subsidaries. Furthermore, foreign ownership requires more control over its management because of conflict of interest between management of subsidiaries 
and the owner of foreign companies (Niemi, 2005). This finding supported the one of Nelson \& Rusdi (2015). Therefore, it is hypothesized that:

H2: firms with large foreign ownership are likely to have larger audit fees.

\subsection{Government Ownership on Audit Fees}

Jensen \& Meckling (1976) stated that according to agency theory, companies with good governance mechanisms are expected to reduce agency conflicts, one of which is the cost of supervising companies' management activities. The reduced conflict might happen due the existence of a good internal corporate system, in which manager will be difficult to manipulate the financial report.

Governmental ownership differs from the other forms of ownerships as the state-owned corporations are ultimately financed by money that belongs to the people of the state, and the ultimate ownership is extremely dispersed. This creates a more pronounced free-rider problem compares to big listed companies. With a diffused ownership structure, shareholders have no strong incentive to monitor directly the management themselves because each shareholder has only a small investment in the firm. As a result, in the government owned companies, as internal control system is low, the agency problem is high; thus, external auditors are needed. Chan et al. (1993) suggested that companies' shareholders with widely dispersed ownership depend on a greater reliance on auditing as a mean of monitoring to managerial behavior. This finding supported study of Nelson \& Rusdi (2015).It is thus hypothesized that:

H3: firms with large government ownership are likely to have larger audit fees.

\subsection{Complexity on Audit Fees}

In agency theory, because of asymmetric information between managers and business owners, it is increasingly difficult for shareholders to determine whether managers are manipulating or not. So, to oversee the activities of the manager, the owner employ an external auditor as a representative of the owner to oversee the manager and ensure the credibility of the financial statements (Jensen \& Meckling, 1976).

The complexity of the company might be caused by transactions using foreign currency, the number of subsidiaries, the number of branches, or the existence of business operations abroad Cameran 2005). Client's complexity variables are proxy using inventory and account receivables divided by total assets (Niemi, 2005). In doing the auditing, external auditors need more time and effort to understand the client's business operations that in return affect the audit cost which will be higher. Gonthier-Besacier \& Schatt (2007); Hay et al. (2006); and Nelson \& Rusdi (2015) found a positive relationship between client complexity and audit costs. Given this situation, the formulated hypothesis is:

H4: firms with large complexity are likely to have larger audit fees.

\subsection{Current Ratio on Audit Fees}

In determining the amount of audit fees, auditors consider the behavior of the client. For example, a company has a weakened corporate financial condition or higher risk of failing to pay its obligations. It is the responsibility of the auditor to ensure that the annual report is free from material misstatement. In this regard, the auditor will request compensation related to additional work to reduce audit risk. Previous research has examined when any risk action made by the client could lead to increased audit costs (Ghosh, 2011; Nelson \& Rusdi, 2015; Wahab et al., 2011). In this study, the measurement used to measure business risk is the current ratio. Based on the description, it is hypnotized that:

H5: firms with large current ratio are likely to have lower audit fees.

\subsection{Leverage on Audit Fees}

Leverage is intended to illustrate the client's business risk; the greater the potential risk of a company to be bankrupt, the more the management try to misstate the financial statements. Consequently, the more effort the auditor attempt to do (O'Keefe, Simunic, \& Stein, 1994) and the more time the auditor need to reduce the risk, the higher the audit fee imposed will be (Nelson \& Rusdi, 2015). In fact, there is a positive relationship between leverage and audit costs (Yatim et al. (2006); Nelson \& Rusdi (2015). Therefore the hypothesis is:

H6: firms with large leverage are likely to have larger audit fees.

\subsection{Profitability on Audit Fees}

In agency theory, following Jensen \& Meckling (1976), as agents are employed by principals to fulfill their interests, the managers as agents of a company have responsibility to make profits. However, as a result of asymmetric information, 
between the manager and the owner of the company, the owners find difficulties to determine whether managers do manipulation or not (Jensen \& Meckling, 1976). To avoid such agency conflict that may reduce the profits, the owners hire services from external auditors to be their representative to ensure the quality of the companies' financial statements.

Profitability is an important indicator of the management performance that should be controlled for the needs of audit work. According to Joshi \& Al-bastaki (2000) and Nelson \& Rusdi (2015), firms reporting high profits are subject to high public attention to ensure the integrity and reputation of the company. Therefore, as auditors audit the revenue and the expense of the company, the auditors' effort will turn into an increase in audit fees. Based on the description above, hypothesis is formulated:

H7: firms with large profitability are likely to have larger audit fees.

\section{DATA AND METHODOLOGY}

\subsection{Variable Measurement}

The dependent variable used in this study was the level of audit fees charged to the client by an external audit represented as AFEE, measured in the Indonesia rupiah obtained directly from the financial statements. Meanwhile, the independent variables were the ownership structure of the company consisted of: (1) managerial ownership, (2) foreign ownership, (3) government ownership; and characteristics structure, which is divided into: (4) complexity, (5) current ratio, (6) leverage, (7) profitability

The independent variables were measured using stock ownership shareholders of management, foreign, and government, generated from the percentage of share ownership issued in the company's annual report. A company is categorized as managerial ownership if the percentage of ownership shares owned by management is larger than the average percentage shares owned by the company's management. The variable of the foreign ownership structure was measured by the percentage of share owned by both individual and non-individual foreigners. The government ownership was measured by the percentage of shares owned by Government of the Republic Indonesia.

Companies' ownership structure was measured using dummy variable. Code 1 was used when the company category met the criteria of the ownership structure; whereas, 0 was used when the company category did not meet the ownership criteria structure. Meanwhile, the independent variables of the company characteristics were measured by inventory and account receivables divided by total assets (Niemi, 2005) to describe the complexity of a company. The variable used to measure the level of corporate risk based on the company's financial strength in dealing with short-term liabilities was current ratio, which is current assets divided by current liabilities (Ghosh, 2011; Wahab et al., 2011).

Meanwhile, the variable used to describe the level of corporate risk based on the use of debt to finance was leverage, which is the total of debt divided by total assets (Ebrahim, 2010; Yatim et al., 2006). Furthermore, the variable used to measure the company's ability to make a profit was profitability, which is the amount of profit before tax divided by total assets (Joshi \& Al-bastaki, 2000).

\subsection{Sample Selection}

The population of this study, all non-financial companies using currency rupiah listed in the stock exchange of Indonesia within the period of 2014-2016, was purposively sampled. Of all sampled, 150 of non-financial companies matched the criteria.

\subsection{Method of Analysis}

Multiple linear regression was used to test the hypothesis. The equation of multiple regression model is as follows:

The data used was secondary data gathered from Indonesian Stock Exchange Report during 2014-2016. Meanwhile, the tool used to analysis the data was Multiple Linear Regression (Ghozali, 2012). This analysis tool was chosen as it was able to answer the objective of this study; therefore, the findings were expected to describe whether audit cost had a positive or negative influence on foreign ownership, government ownership, profitability, and current ratio.

Based on the theoretical framework and the previous research, the equation of the multiple regression model of this study is formulated as follows:

LNAFEE $=\beta 0+\beta 1($ MOWN $)+\beta 2($ FOWN $)+\beta 3($ GOWN $)+\beta 4($ INVREC $)+\beta 5($ C.RATIO $)+\beta 6($ LEV $)+\beta 7(($ ROA $)+\varepsilon$

LNAFEE : Natural log of total value of audit fees paid to the external auditors by the firms

MOWN : Managerial ownership 


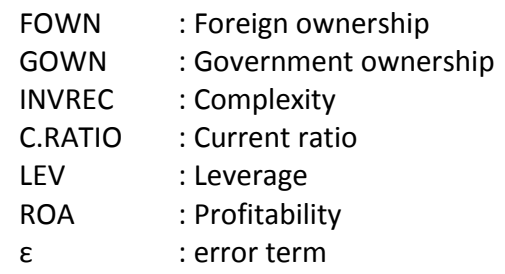

\section{FINDINGS AND DISCUSSIONS}

\subsection{Descriptive Analysis}

All non-financial companies listed in Indonesia as population of the research was purposively sampled and the result turned out to be 150 non-financial companies were eligible as they met the predetermined criteria. Table 1 describe the descriptive statistic of the samples.

Table 1: Descriptive Statistics

\begin{tabular}{l|r|r|r|r|r} 
& N & Minimum & Maximum & Mean & Std. Deviation \\
\hline AFEE & 150 & 46750000.00 & 4550765000.00 & 907928004.7800 & 1087946405.79674 \\
\hline LNAFEE & 150 & 17.66 & 22.24 & 19.9823 & 1.15469 \\
\hline INVREC & 150 & .00 & .80 & .2517 & .19323 \\
\hline CRATIO & 150 & .00 & 464.98 & 6.8014 & 38.30937 \\
\hline LEV & 150 & .00 & 1603.50 & 21.0345 & 178.14555 \\
\hline ROA & 150 & -.32 & .87 & .0688 & .10068 \\
\hline MOWN & 150 & .00 & .51 & .0265 & .07993 \\
\hline FOWN & 150 & .00 & .97 & .2446 & .29769 \\
\hline GOWN & 150 & .00 & .76 & .0940 & .22344 \\
\hline Valid N (listwise) & 150 & & & & \\
\hline SOUCe: Seconday & 150 & & &
\end{tabular}

Source: Secondary data processed, 2018

Table 1 shows the descriptive statistics of the minimum, average, and standard deviation of the variables used in this study.

\subsection{Dummy Variable}

The independent variables consisted of ownership structure as dummy variable and the characteristics of the company. Table 2 shows the frequency of the dummy variable.

Tabel 2: Dummy Variable Frequency

\begin{tabular}{|c|c|c|c|}
\hline Variable & & Frequency & Percentage \\
\hline \multirow{2}{*}{ MOWN } & $\begin{array}{l}\text { MOWN=1 companies with shares owned by managerial is } \\
\text { higher than } 2.65 \%\end{array}$ & 109 & $72.67 \%$ \\
\hline & $\begin{array}{l}\text { MOWN=0 companies with shares owned by manajerial is } \\
\text { lower than } 2.65 \%\end{array}$ & 41 & $27.33 \%$ \\
\hline \multirow{2}{*}{ FOWN } & $\begin{array}{l}\text { FOWN }=1 \text { companies with shares owned by foreign is } \\
\text { higher than } 24.46 \%\end{array}$ & 127 & $84.67 \%$ \\
\hline & $\begin{array}{l}\text { FOWN }=0 \text { companies with shares owned by foreign is } \\
\text { lower than } 24.46 \%\end{array}$ & 23 & $15.33 \%$ \\
\hline \multirow{2}{*}{ GOWN } & $\begin{array}{l}\text { GOWN =1 companies with shares owned by government is } \\
\text { higher than } 9.4 \%\end{array}$ & 114 & $76 \%$ \\
\hline & $\begin{array}{l}\text { GOWN }=0 \text { companies with shares owned by government is } \\
\text { lower than } 9.4 \%\end{array}$ & 36 & $24 \%$ \\
\hline
\end{tabular}

Source: Secondary data processed, 2018 
Table 2 shows the proportion of the samples having score of higher or lower than the average value (descriptive statistic). In the managerial ownerships (MOWN), $72.67 \%$ samples are above the average value of $2.65 \%$; while, others are lower than the average value. In the foreign owned companies, the number of samples having higher than the average score of $24.46 \%$ is $84.67 \%$; while, the rest, $15.33 \%$, has below average score. Meanwhile, in the government owned companies, the number of samples having higher than the average score of $9.4 \%$ is $76 \%$; while, the rest, $24 \%$, has below average score.

Before performing regression analysis, the model was tested using classical assumption to identify whether the model was free from the problems of normality test, multi-colonierity test, autocorrelation test, and heterokedasticity test.

The first hypothesis tested showed that managerial ownership had a negative relationship on audit fees; there was insufficient evidence to support firms with managerial ownership that tended to lead to lower audit fees. This result was supported by the research of Niemi (2005) that managerial ownership variables were negatively related to audit fees.

Table 3: Results of Hyphothesis

\begin{tabular}{lc|c|c|c|c|}
\multicolumn{2}{c}{ Unstandardized Coefficients } & Standardized Coefficients & & \\
Model & B & Std. Error & Beta & t & Sig. \\
\hline 1 (Constant) & 19.743 & .179 & & 110.392 & .000 \\
\hline MOWN & -2.243 & 1.090 & -.155 & -2.058 & .041 \\
\hline FOWN & .674 & .300 & .174 & 2.250 & .026 \\
\hline GOWN & 1.017 & .401 & .197 & 2.539 & .012 \\
\hline INVREC & -.815 & .450 & -.136 & -1.811 & .072 \\
\hline CRATIO & -.002 & .002 & -.068 & -.900 & .369 \\
\hline LEV & .001 & .000 & .110 & 1.443 & .151 \\
\hline ROA & 3.530 & .878 & .308 & 4.020 & .000 \\
\hline
\end{tabular}

a. Dependent Variable: LNAFEE

The result of the second hypothesis showed that the foreign ownership had a positive relationship on audit fees, which was in line with previous research of Niemi (2005). The increase of the audit fees took place as the foreign ownership tended to have high complexity of financial reporting and geographical differences. The reporting of the company's financial statements would be more complex when the parent company was located in a different country from its subsidiaries due to different accounting rules and standards in each country.

The result of the third hypothesis showed that the government ownership had a positive relationship with audit fees, which was in line with the study of Chan et al. (1993); and Nelson \& Rusdi (2015). In agency theory, companies with good governance mechanisms are expected to reduce agency conflicts, one of which is the cost of supervising company management activities (Jensen \& Meckling, 1976).

The audit fees of the government ownership companies tended to increase because public financed government-controlled companies were fragmented or dispersed. Such ownership tended to have low interest in overseeing the performance of the managers making it difficult for external auditors and increased the audit fees.

The result of the fourth hypothesis showed that the client complexity did not have a significant relationship on audit cost, as there was not enough evidence to support that companies with complex client complexity tended to lead to higher audit fees. This was in accordance with previous research by Nelson \& Rusdi (2015); and Niemi (2005) that client complexity had no effect on audit fees.

The result of this hypothesis tested contradicted with Gonthier-Besacier \& Schatt (2007); and Hay et al. (2006) that client complexity positively affected audit costs because clients with complex business required more effort and time on external auditors to fully understand business operations of the clients. In other words, the more the time spent on doing the audit procedures, the higher the audit cost will be. 
This can be proven from the company's research data ASSA code in 2014 has an INVREC amount of 0.063 with an audit fee of Rp 744,000,000 while a company with CTTH code has an INVREC amount of 0.698 but only pays an audit fee of Rp $300,000,000$. This shows that not all companies with high complexity will be charged a high audit cost as well.

This result allegedly caused by companies that have high inventory and accounts receivable have good accounting information systems and good internal controls so that companies can handle the number of transactions efficiently and effectively. This certainly facilitates external auditors so that client complexity does not affect towards audit fees.

The result of the fifth hypothesis showed that current ratio did not affect audit fee. This finding was in line with the one of Baldacchino, et al. (2014) as public accountant firm considered audit risk and business of the clients very low.

The result of the sixth hypothesis showed that the leverage did not affect the audit fees. This indicated that there was not enough evidence to support the firms with high leverage ratios. This indication led to the increase of the audit fees that external auditors charged on their clients. The result of this test was not in accordance with previous research by Nelson \& Rusdi, (2015); and Yatim et al. (2006) that the greater the potential risk of companies to go bankrupt, the more the management try to misstate the financial statements; so that, the auditors need more performance to reduce such risks. However, this was in line with the previous research conducted by Oktorina \& Wedari (2015) that leverage had no effect on audit costs.

This can be seen from the research data by the company with INTP code where the company has LEV of 0.149 and the audit fees of Rp 3.612.000.000 while the company with the code CTTH have LEV of 0.771 with audit fees of Rp 300,000,000

The results of the seventh hypothesis showed that profitability had a positive relationship on audit fees. This was in line with the research of Joshi \& Al-bastaki (2000) that companies reporting high profits were subject to high public attention; therefore, to save the integrity and the reputation of the company, the auditor audited the income and also the expense of the company, that in turn increased the audit fees.

\section{CONCLUSION}

The results of this study indicate several factors affecting the amount of audit fees paid by the company. The results show a significant positive relationship between auditing fees and firms with greater foreign ownership, government ownership, and profitability but there is a significant negative relationship with firms with higher managerial ownership. The results also indicate a non-significant relationship between audit fees and firm complexity as well as leverage and current ratio.

This study has several limitations. Firstly, there is little disclosure of audit fees in the company's annual report, making the number of research samples small. Secondly, the regression model has $21.1 \%$ of the factors that affect audit fees. Third, this study uses the total cost paid to the external auditor as an audit fees; whereas, in the audit cost there may be assurance services and non assurance services

Based in these limitations, further research is expected to add other variables besides the regression model such as firm size, auditor size, and audit committee characteristics in order to explain factors outside the regression model.

\section{REFERENCES}

Adelopo, I., Jallow, K., \& Scott, P. (2012). Multiple large ownership structure, audit committee activity and audit fees: Evidence from the UK. Journal of Applied Accounting Research, 13(2), 100-121.

Baldacchino, Peter.J, et.al. (2014). Factors Infulencing External Audit Fees in Malta. Bank of Valletta Review, 48, 26-40

Cameran, M. (2005). Audit Fees and the Large Auditor Premium in the Italian Market. International Journal of Auditing Int. J. Audit. Int. J. Audit, 9(9), 129-146.

Chan, P., Ezzamel, M., \& Gwilliam, D. (1993). Determinates of audit fees for quoted UK companies. Journal of Business Finance \& Accounting, 20(6), 765-786.

Ebrahim, A. (2010). Audit fee premium and auditor change: the effect of Sarbanes-Oxley Act. Managerial Auditing Journal, 25(2), $102-121$.

Fafatas, S. A., \& Jialin Sun, K. (2010). The relationship between auditor size and audit fees: further evidence from big four market shares in emerging economies. Research in Accounting in Emerging Economies (Vol. 10).

El-Gammal, Walid.(2012). Determinants of Audit Fees:Evidence from Lebanon. International Business Research. 5(11), 136-145

Ghosh, S. (2011). Firm ownership type, earnings management and auditor relationships: evidence from India. Managerial Auditing Journal, 26(4), 350-369. 
Ghozali, Imam, 2012. Aplikasi Analisis Multivariate Dengan Program IBM SPSS 20.Edisi 6. Badan Penerbit Universitas Diponegoro, Semarang.

Gonthier-Besacier, N., \& Schatt, A. (2007). Determinants of audit fees for French quoted firms. Managerial Auditing Journal, 22(2), 139160 .

Griffin, P. A., Lont, D. H., \& Sun, Y. (2009). Governance regulatory changes, International Financial Reporting Standards adoption, and New Zealand audit and non-audit fees: Empirical evidence. Accounting and Finance, 49(4), 697-724.

Hay, D., Knechel, W. R., \& Wong, N. (2006). Audit Fees: A Meta-analysis of the Effect of Supply and Demand Attributes. Contemporary Accounting Research, 23(1), 141-91.

Hogan, C. E., \& Wilkins, M. S. (2008). Evidence on the audit risk model: Do auditors increase audit fees in the presence of internal control deficiencies? Contemporary Accounting Research, 25

Hoitash, R., Markelevich, A., \& Barragato, C. a. (2007). Auditor fees and audit quality. Managerial Auditing Journal, 22(8), 761-786.

Jensen, M. C., \& Meckling, W. H. (1976). Theory of the Firm: Managerial. Journal of Financial Economics, 3, 305-360.

Joshi, P. L., \& Al-bastaki, H. (2000). Determinants of Audit Fees : Evidence from the Companies Listed in Bahrain, 138(January), 129-138.

Mazlina Mustapha, \& Ayoib Che Ahmad. (2011). Agency Theory and Managerial Ownership: Evidence from Malaysia. Managerial Auditing Journal, 26(5), 419-436.

Mitra, S., Hossain, M., \& Deis, D. R. (2007). The empirical relationship between ownership characteristics and audit fees. Review of Quantitative Finance and Accounting, 28(3), 257-285.

Nelson, S., \& Rusdi, N. (2015). Journal of Accounting in Emerging Economies Article information

Niemi, L. (2005). Audit effort and fees under concentrated client ownership: Evidence from four international audit firms. International Journal of Accounting, 40(4), 303-323.

O’Keefe, T. B., Simunic, D. A., \& Stein, M. T. (1994). The Production of Audit Services: Evidence from a Major Public Accounting Firm. Journal of Accounting Research, 32(2), 241-261 CR-Copyright169; 1994 Accounting

Oktorina, M., \& Wedari, L. K. (2015). An Empirical Investigation on Ownership Characteristics, Activities of the Audit Committee, and Audit Fees in Companies Listed on Indonesia Stock Exchange. Applied Finance and Accounting, 1(1), 20-29.

Simunic, D. (1980). The Pricing of Audit Services: Theory and Evidence. Journal of Accounting Research, 18, 161-190.

Wahab, E. A. A., Zain, M. M., \& James, K. (2011). Audit fees in Malaysia: Does corporate governance matter? Asian Academy of Management Journal of Accounting and Finance, 7(1), 1-27.

Yatim, P., Kent, P., \& Clarkson, P. (2006). Governance structures, ethnicity, and audit fees of Malaysian listed firms. Managerial Auditing Journal, 21(7), 757-782. 